\title{
$\mathrm{HMM}$ 을 이용한 제스처 인식 기반 한자 학습 콘텐츠 송대현 ${ }^{+}$김동민 ${ }^{++}$, 이칠우 ${ }^{++}$
}

요 약

본 논문에서는 $\mathrm{HMM}$ 을 이용한 제스처 인식을 입력 인터페이스로 사용한 한자 학습 콘텐츠에 대해 제안한 다. 제안한 시스템의 입력정보는 TOF 카메라 영상으로부터 3차원 정보를 받으며, 제스처 인식 방법은 사용자 의 포즈를 예측하는 부분과 연속된 포즈들로부터 제스처를 인식하는 부분으로 구성되어 있다. 사용자와 컴퓨터사이의 의사소통에서, 별도의 추가 장비를 사용하지 않고 사용자의 행동에 의한 조작을 통해 사용자가 쉽게 조작할 수 있도록 편리함을 제공하였다. 또한 대형 디스플레이와 다양한 멀티미디어 요소를 이용하여 몰입과 흥미를 유발시킬 수 있기 때문에 정보 전달을 극대화할 수 있다. 본 논문에서 제안한 에듀테인먼트 한자 학습 콘텐츠는 교육적 내용를 제공하고 사용자가 흥미를 느끼도록 하여 자연스레 한자를 습득할 수 있고, 제스처 인식을 기반으로 하므로 사용자에게 콘텐츠 체험을 통한 시너지 효과를 기대할 수 있다.

\section{The Chinese Characters Learning Contents Based on Gesture Recognition Using HMM Algorithm}

\author{
Dae-Hyeon Song ${ }^{\dagger}$, Dong-Min Kim ${ }^{++}$, Chil-Woo Lee ${ }^{+++}$
}

\section{ABSTRACT}

In this paper, we proposed a contents of Chinese characters learning based on gesture recognition using HMM(hidden markov model) algorithm. Input image of the system is obtained in 3-dimensional information from the TOF camera, and the method of gesture recognition is consisted of part of forecasting user's posture in two infrared images and part of recognizing gestures from continuous poses. In the communication between human and computer, this system provided convenience that user can manipulate it easily by not using any further equipment but action. Because this system raise immersion and interest by using two large display and various multimedia factor, it can maximize information transmission. The edutainment Chinese character contents proposed in this paper provide educational effect that use can master Chinese character naturally with interest, and it can be expected a synergy effect via content experience because it is based on gesture recognition.

Key words: HMM algorithm(HMM 알고리즘), Gesture Recognition(제스처 인식), Edutainment Contents(에듀테인먼트 콘텐츠)

\section{1. 서 론}

오늘날 과학 기술이 발달되고 다양한 디바이스와

※ 교신저자(Corresponding Author): 이칠우, 광주 북구 용봉동 전남대학교 전자컴퓨터공학, 전화 : 062)530-1803, FAX : 062)530-0223, E-mail : leecw@chonnam.ac.kr 접수일 : 2012년 2월 15일, 수정일 : 2012년 5월 4일 완료일 : 2012년 6월 22일
인터페이스들이 등장하여 사용자들의 편리함을 추 구할 수 있는 사용자 중심의 인터페이스 분야가 활발 히 연구되고 있다. 사용자는 기존의 입력도구를 이용

\footnotetext{
${ }^{+}$준회원, 전남대학교 전자컴퓨터강학과 박사과정 (E-mail:min2man@nate.com)

${ }^{++}$준회원, 전남대학교 전자컴퓨터공학부 석사과정 (E-mail:kdmin17@nate.com)

${ }^{+++}$종신회원, 전남대학교 전자컴퓨터공학부 교수 (E-mail: leecw@chonnam.ac.kr)
} 
하여 인터페이스를 조작하고 콘텐츠와 긴밀한 상호 작용이 하길 원한다. 하지만 이러한 입력방식은 한계 가 드러났고 그에 대처 방안으로 키보드나 마우스 대신할 수 있는 비전 기반의 제스처, 센서를 이용한 터치, 음성을 이용한 조작 등 많은 기술들이 등장하 였다[1]. 그리고 콘텐츠 또한 이러한 기술들에 영향 을 받아 단순한 정보를 전달하는 것으로 끝나는 것이 아니라, 사용자간의 피드백이 중요하게 되었고 최신 기술이 적용된 인터페이스들과의 상호작용성이 보 다 더 중요하게 되었다. 예를 들어, 교육에 놀이나 오락을 도입한 에듀테인먼트 콘텐츠가 각광받고 있 다[2].

그리하여 최신기술 발달과 함께 인터페이스 기술 들이 발전되어져가고 있고, 이를 꾸며줄 콘텐츠 분야 역시 각광을 받고 있다. 하지만 최신 인터페이스 및 콘텐츠들은 사용자에게 편리함보다는 기술력의 우 월함을 보여주고, 정보제공 능력 보다는 화려함을 추 구하였다. 이러한 문제점을 보완하기 위하여, 본 논 문에서 직접적인 체험과 경험을 통해 효과적으로 학 습한다는 개념을 중심으로 사용자에게 공감각의 다 양성과 즐거움을 제공할 뿐만 아니라 조작의 자유도 를 높혀 사용자에게 편리함을 제공하였다. 또한 놀이 를 통하여 자연스럽게 학습할 수 있도록 제스처 인식 을 기반으로 하는 한자 학습 콘텐츠에 대하여 기술 한다.

\section{2. 관련 연구}

최근 인터페이스 기술은 게임, 영화, 문화, 주거 등 다양한 분야에 적용되어지고 있다. 이러한 인터페이 스 기술들 중에 대표적인 기술인 센서 기반 기술과 카메라 비전(Vision) 기반 기술에 대해 간단히 소개 한다.

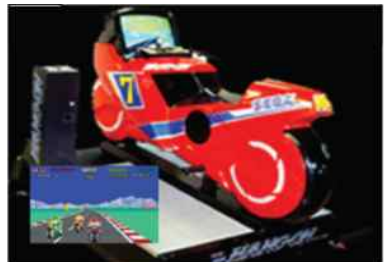

(a)

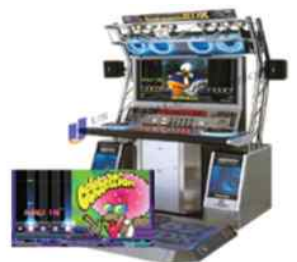

(b)

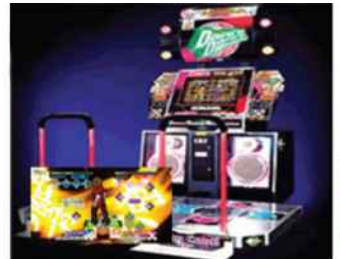

(c)

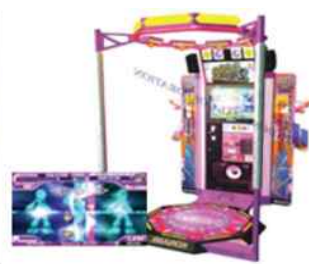

(d)

그림 1. 세서 기바 이터페이스 기술의 예 : (a) Hang-On para paradise 
을 할 수 있으며 응용하여 실제 춤으로 구성도 가능 했다.

\section{2 카메라 비전 기반 인터페이스 기술}

카메라 비전 처리 기술을 이용해서 모션 캡처한 데이터를 활용하는 인터페이스이다. 플랫폼 자체가 고정된 카메라와 디스플레이로 정해져 있고 크기가 작고 가볍기 때문에 가정에서 활용하기에 적합하다. Eyetoy 그림 2(a)는 플레이스테이션2에서 비전 기술 과 혼합 현실 기술(Mixed Reality)을 적용한 콘텐츠 를 제공한다[3]. 이 방식은 매우 간단한 구조를 가지 고 있다는 장점이 있지만 항상 카메라를 쳐다보며 플레이해야 한다는 것과 신체가 카메라 밖을 벗어나 면 인식이 되지 않는다는 것이 단점이 있다. Eye Pet 은그림 2(b) SONY(Playstation2)에서 최근 발매된 증강현실(Augmented Reality)을 이용한 애완동물 키우는 게임이다. 원숭이 같이 생긴 애완동물이 등장 하고 사용자와 몇 가지 흥미로운 인터랙션을 할 수 있다. 소리에도 반응하고 흰색 바탕 위에 검정색으로 그림을 그려 보여주면 원숭이가 똑같이 따라 그린다. 그리고 이것은 곧 3 차원 물체가 되어 게임컨트롤러 로 조정할 수 있다. 또한 배설물 치우는 일부터 목욕, 먹이주기, 놀아주기 등 실제 애완동물을 키우는 요소
로 사용자에게 몰입감을 주고 현실감을 준다.

\section{3. 시스템 구조}

본 논문에서 제안된 시스템의 하드웨어는 대형 디 스플레이와 1 대의 $\mathrm{TOF}$ 카메라, 진동 발판, $\mathrm{LED}$ 로 구성된다(그림 3). TOF 카메라는 3차원 정보를 받아 사용자의 포즈 및 제스처 인식을 하는 영상 장치이 며, $\mathrm{LED}$ 는 다양한 효과를 내기 위해 사용된다. 발판 은 4구역으로 나누어져 있으며, 캐릭터의 이동과 기 타 선택을 위해 사용되며 진동을 주는 장치이다. 또 한 타임머신의 컨셉으로 사용자가 좀 더 콘텐츠에 몰입할 수 있도록 유도하였다. 내부 소프트웨어 구성 은 콘텐츠의 시나리오 진행에 따라 영상을 디스플레 이하는 그래픽 처리 부분과 사용자와 콘텐츠 간의 상호작용을 위한 제스처 인식 부분으로 구성된다.

\section{4. 한자 학습 콘텐츠}

\section{1 한자 학습 콘텐츠 개요}

처음 에듀테인먼트가 등장하면서 최초 콘텐츠의 대부분은 $\mathrm{CD}-\mathrm{ROM}$ 의 콘텐츠가 대부분이었으나 디 지털기술의 발달에 맞춰 온라인 시장으로 발전되어
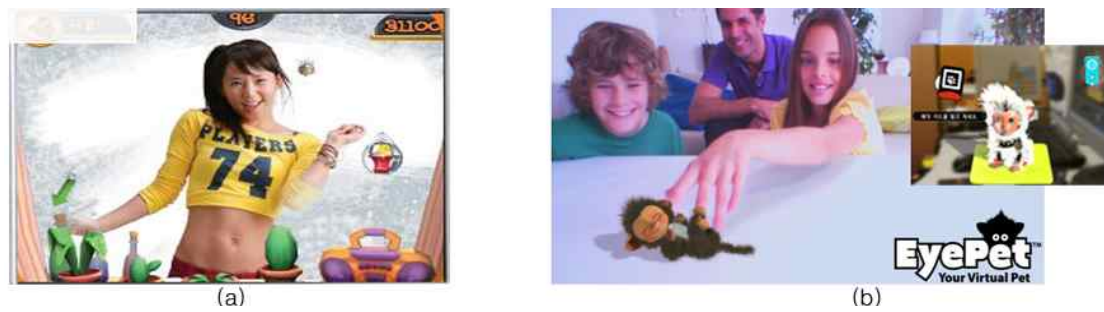

(b)

그림 2. 카메라 비전 기반 인터페이스 기술의 예 : (a) EyeToy (b) EyePet

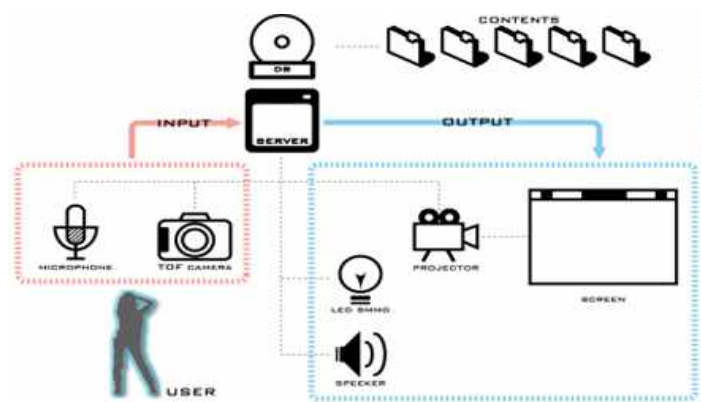

(a)

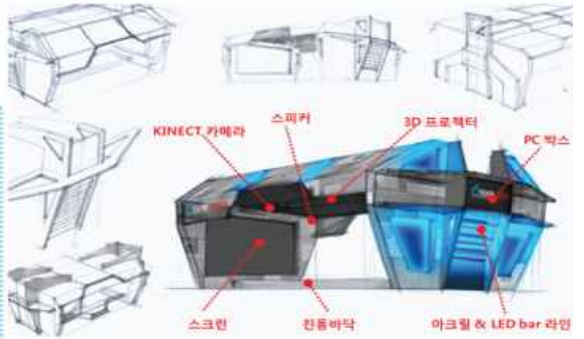

(b)

그림 3. 시스템 구조 : (a) 시스템 구성 (b) 시스템 하드웨어 
나가고 있다. 하지만 세계 각국의 전자관련 업체들이 컴퓨터관련 교육용 게임분야를 멀티미디어 핵심 산 업으로 인식하여 주도권을 확보하고자 집중적으로 투자를 하는 반면에 국내에서는 “에듀테인먼트" 단 어 자체를 모르는 사용자가 많았고 콘텐츠 제작 및 유통이 취약한 실정이다. 하지만 이러한 협소한 환경 속에서도 국내 에듀테인먼트 콘텐츠는 질적인 면에 서 인정을 받고 있어 시장만 확대된다면 많은 발전이 예상되고 지금까지는 대상이 아동이 주류였다면, 지 식사회로의 발전과 평생교육에 대한 수요증가로 인 해 대상이 넓어질 것으로 예상된다. 본 논문에서 제 안하는 한자 학습 콘텐츠는 제스처 인식 기반의 시스 템 환경 안에서 게임을 즐기면서 학습효과를 올릴 수 있도록 제작되었다.

\section{2 콘텐츠 구성}

본 시스템에 적용된 한자 학습 콘텐츠는 게임을 하면서 자연스럽게 한자를 학습하도록 유도하는 에 듀테인먼트 콘텐츠이다. 사용자는 추가 장비의 도움 없이 다양한 몸동작을 사용하고 시스템 안에서 위치 를 이동함으로써 콘텐츠를 조작할 수 있다. 콘텐츠 구조는 주요화면인 중앙 디스플레이와 보조화면인 보조 디스플레이, 그리고 발판으로 구성되어 있다. 주요화면에서는 사용자를 대신하는 캐릭터와 몬스 터가 나오고 시나리오를 진행하는 부분이고 보조화 면에서는 사용자가 획득한 한자(공격, 방어, 기타)를 보여주고 선택할 수 있게 도와주는 부분이다. 그리고 발판은 총 4 구역으로 나뉘어져 있고 캐릭터의 이동 및 기타 선택을 할 수 있는 부분으로 구성되어 있다.

\section{3 콘텐츠 시나리오}

한자 학습 콘텐츠는 크게 도입부와 실행부로 나뉜 다(그림 4). 도입부에서는 사용자가 시스템 안으로 접근하기 전까지 영상물을 반복하여 보여준다. 사용 자가 시스템에 접근하면 도입부의 동영상이 정지되 고 게임 모드 선택화면으로 넘어간다. 게임모드는 연 습모드와 실전모드로 나뉜다. 연습모드는 콘텐츠에 서 사용될 제스처들을 미리 학습할 수 있도록 도와주 는 것이다. 사용자는 발판을 중심으로 상, 하, 좌, 우 움직임으로 콘텐츠의 모드를 선택할 수 있고 이 중 한 가지 모드를 선택하면 게임 방법 설명과 아이템 설명이 차례로 나오며 게임 스테이지로 넘어간다.

실행부에서는 총 3 개의 스테이지로 나뉘어져 각 각의 스테이지마다 한자의 속성을 가진 몬스터가 등 장한다. 한자의 속성을 가진 몬스터는 해당 성격의 반대되는 성격의 한자의 기술을 이용하여 공격을 해 야 하고 동질의 성격일 경우 공격이 되지 않는다. 공 격과 방어, 아이템 선택 등 콘텐츠를 조작하기 위해 서는 표 1 에서 정의된 다양한 제스처를 사용해야한다.

\section{표 1. 게임 콘텐츠 활용을 위해 정의된 제스처}

\begin{tabular}{|c|c|c|}
\hline 제스처 & 이벤트 설명 & 이벤트 실행 \\
\hline \hline \multirow{2}{*}{$\begin{array}{c}\text { 이동 관련 } \\
\text { 제스처 }\end{array}$} & 상, 하, 좌, 우 & 아바타 이동 \\
\cline { 2 - 3 } & 경공 & 아바타 공중 부양 \\
\hline \multirow{2}{*}{$\begin{array}{c}\text { 공격 관련 } \\
\text { 제스처 }\end{array}$} & 장풍 쏘기 & 장풍 공격 \\
\cline { 2 - 3 } & 칼로 베기 & 칼베기 공격 \\
\cline { 2 - 3 } & 투척 & 아이템 던지기 \\
\hline $\begin{array}{c}\text { 보조 화면 } \\
\text { 조작 }\end{array}$ & 좌, 우, 선택 & $\begin{array}{c}\text { 아이템 및 한자 } \\
\text { 선택 }\end{array}$ \\
\hline
\end{tabular}

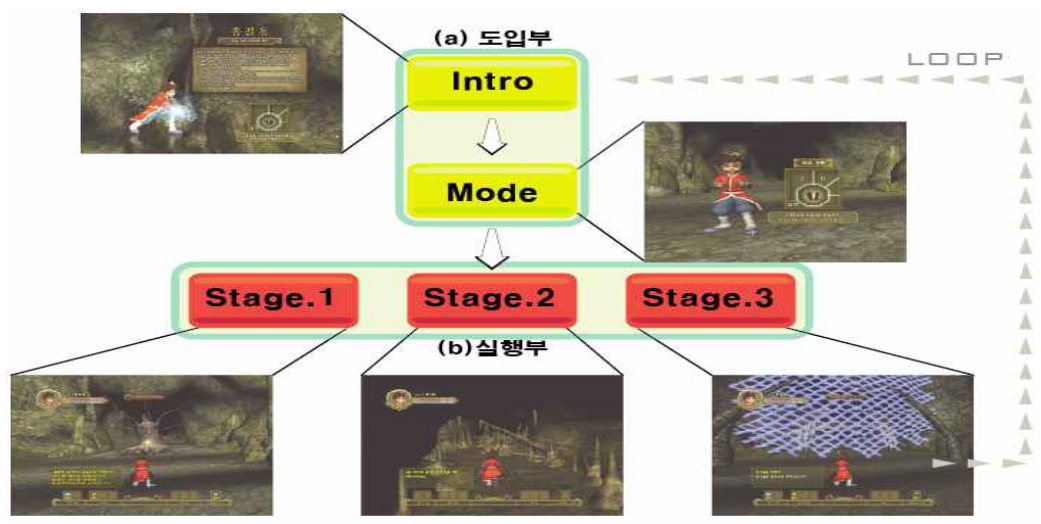

그림 4. 콘텐츠 시나리오 
이렇듯 실제 콘텐츠에서는 한자의 속성을 지닌 몬 스터들이 등장하고 사용자는 거기에 상반되는 한자 를 숙지하고 있어야 시나리오를 진행할 수 있기 때문 에 사용자에게 한자를 쉽게 습득할 수 있도록 도와 준다.

\section{5. 제스처 인식}

\section{1 제스처 인식 기반 시스템의 개요}

본 논문에서 제안하는 제스처 인식 기반 시스템은 멀티모달 제스처 인식 기술로써, 사용자와 콘텐츠간 의 제스처 인식을 이용한 상호작용을 통해 사용자에 게 효율적으로 정보와 재미를 준다. 그리고 사용자가 콘텐츠를 체험함으로써 자발적 동기를 부여할 수 있 기 때문에 사용자가 단순히 콘텐츠가 주는 정보를 제공받는 '관찰자'로 그치지 않고 적극적인 '참여자' 로 유도하는 할뿐 아니라 기존의 센서기반의 인터페 이스 시스템과 달리 비전기술과 센서기술 등 최신 기술을 접목시켜 사용자에게 현실과 가상세계를 모 호하게 만들어, 콘텐츠에 몰입할 수 있도록 하는 시 스템이다[4]. TOF카메라로부터 깊이 이미지 정보를 얻어 전처리 과정을 거친 뒤 $\mathrm{EOH}$ 와 $\mathrm{SVM}$ 을 이용하 여 포즈분석을 한다. 그리고 마지막으로 순차적 포즈 들을 나열해서 HMM알고리즘을 이용하여 제스처를 인식한다.

\section{$5.2 \mathrm{HMM}$ 을 이용한 제스처 인식}

본 논문에서는 ROI(Region of Interest)영상이 포 함하고 있는 36 개의 방향에 분포한 에지의 양을 표현 하는 $\mathrm{EOH}$ 특징을 포즈 정보로 사용한다. $\mathrm{EOH}$ 특징 은 총 36 개의 차원으로 구성되며 총 36 개의 에지방향 을 가지고 있다(그림 5). 36방향의 에지를 얻기 위하 여 하나의 영상에서 다음과 같은 에지의 $\mathrm{x}$ 축과 $\mathrm{y}$ 축
에 대한 에지영상 $G_{x}$ 와 $G_{y}$ 를 추출한다[6]. 그리고 아 래의 식을 통하여 픽셀 $(i, j)$ 의 에지의 방향과 크기를 계산한다.

$$
\begin{aligned}
& G_{x}=\text { Sobel }_{x}\left(I_{R O I}\right), G_{y}=\text { Sobel }_{y}\left(I_{R O I}\right) \\
& \theta_{i, j}=\arctan \left(G_{x}(i, j) / G_{y}(i, j)\right) \\
& m_{i, j}=\sqrt{G_{x}(i, j)^{2}+G_{y}(i, j)^{2}}
\end{aligned}
$$

하나의 포즈마다 36 개의 특징을 통합하여 각 영상 $\mathrm{ROI}$ 의 $\mathrm{EOH}$ 특징에 해당하는 각 픽셀 $(i, j)$ 의 에지크 기 $m_{i, j}$ 를 각 방향성별로 모두 합산을 통해 추출한다. 각각의 포즈의 대한 3 차원 정보를 분류하고 난 뒤, 연속적인 포즈들의 조합으로 제스처 모델을 만든다.

본 논문에서는 제스처 인식을 위해 $\mathrm{HMM}$ 을 사용 하였다[5]. HMM은 시간적으로 제약을 받는 정보의 구조를 모델링 하는데 뛰어난 모델이다. Simple Markov Model만으로 모델링하기 힘든 실세계의 문 제를 통계적 매개변수로 접근할 수 있게 해준다. 상 태 전이 매개 변수는 순차적인 일련의 사건 발생을 모델링한다. 그리고 관측 심볼 확률 분포는 각 사건 의 특징을 유한개의 심볼로 대응시킨다.

$\mathrm{HMM}$ 은 이러한 두 가지 확률 과정의 결합으로 이 루어져 있고, 이 기준에 따라 생성된다. 생성된 $\mathrm{HMM}$ 은 학습 데이터를 이용한 학습을 통해 적절한 제스처 모델을 구성한다. 인식과정에서는 인식하고자 하는 제스처와 학습이 끝난 후 생성된 모든 $\mathrm{HMM}$ 의 제스 처 모델을 비교한다. 그리하여, 가장 유사하다고 판 단되는 제스처 모델을 선택하고 결과를 확률로 나타 낸다. 상태전이확률을 이용하여 각 샘플들을 이용한 전처리 단계는 잡음제거와 대표점 추출 과정을 거쳐 손가락 궤적을 체인코드로 변환하는 과정으로 8 방향 체인코드를 사용한다.

학습 과정은 각 제스처별로 이루어지며, 해당 제 스처의 $\mathrm{HMM}$ 모델에 학습결과를 적용한다. $\mathrm{HMM}$

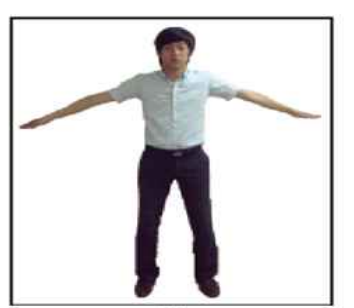

(a)

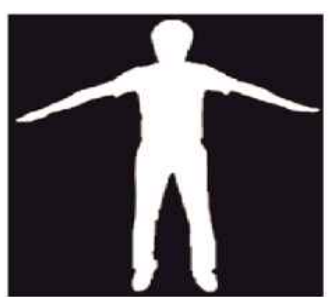

(b)

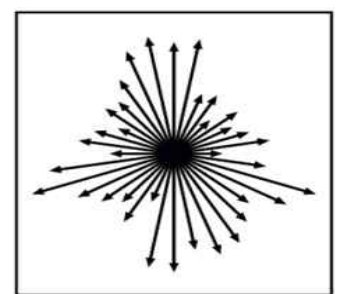

(c)

그림 5. $\mathrm{EOH}$ 특징을 이용한 포즈 정보 : (a) 전경분리 이미지 (b) 실루엣 이미지 (c) 36 방향 에지 벡터 
의 학습 과정은 각 숫자별로 상반신 포즈를 이용하여 은닉 마르코프 모델을 구성하는 과정으로, $\mathrm{EM}$ 알고 리즘의 하나인 Baum-Welch 알고리즘을 이용한다 [7]. $\mathrm{HMM}$ 의 인식 과정은 전처리 모듈을 통해 변환 된 체인코드가 어느 숫자의 은닉 마르코프 모델에서 나타날 확률이 높은가를 판단하는 과정으로, 각각의 숫자 모델에 전향(Forward) 알고리즘을 적용하여 가장 높은 확률을 보이는 숫자 모델을 최종 인식 결 과로 출력한다. $\mathrm{HMM}$ 은 아래와 같은 요소로 구성 된다.

$N$ : 상태의 수,

$S=\left\{S_{1}, S_{2}, \ldots, S_{N}\right\}$ : 상태의 집합,

$q_{t}$ : 시간 $t$ 의 상태

$\square M$ : 관측심볼의수,

$V=\left\{v_{1}, v_{2}, \ldots, v_{M}\right\}:$ 관측심볼의집합

$\square A:\left\{a_{i j}\right\}$ : 상태전이확률 분포

$a_{i j}=P\left(q_{t+1}=S_{j} \mid q_{t}=S_{i}\right), 1 \leq i, j \leq N$

$:$ 상태 $i$ 에서상태 $j$ 로 전이할 확률

$\square B=\left\{b_{t}(k)\right\}:$ 관측심볼 확률 분포,

$b_{j}(k)=P\left(v_{k} \mid q_{t}=S_{j}\right), 1 \leq j \leq N, 1 \leq k \leq M$

$: j$ 에서 심볼 $v_{k}$ 를 관측할 확률

$\square \pi=\left\{\pi_{t}\right\}$ : 초기상태확률 분포,

$\pi_{t}=P\left(q_{1}=S_{i}\right), 1 \leq i \leq N$ : 초기 상태가 $i$ 일 확률

각 제스처는 시작포즈를 가지고 있고 제스처에 해 당하는 상태천이확률이 무효할 경우에는 "IDLE" 상 태를 가지고 있으며, 상태천이확률이 유효한 시점부 터 각 제스처에 해당하는 포즈를 전부 만족할 경우 제스처가 종료된 것으로 판단한다. Left-Right $\mathrm{HMM}$
구조 모델은 포즈 사이에 잡음이 생겨도 미리 학습한 상태천이확률이 유효하므로 실시간 인터페이스로 사용하기에 무리가 없다. 그리고 학습이 끝난 후 제 스처 인식 과정에서는 인식하고자 하는 제스처와 학 습이 끝난 후 생성된 모든 $\mathrm{HMM}$ 의 제스처 모델을 비교하여 확률 값이 가장 높은 제스처 모델을 해당 제스처와 유사하다고 판단하여 선택한다(그림 6).

\section{3 제스처 인식 결과}

실험방법은 총 9 개 제스처를 사용자 10 명이 10 번 씩 실행하였다. 생성된 9 개의 제스처는 13 개의 포즈 중 3 6개의 포즈의 집합으로 구성되어 있으며 포즈 개수에 따른 제스처의 인식률 결과를 보여주고 있다 (표 2)

많은 수의 포즈를 조합하면 정확한 제스처를 표현 할 수 있지만 제스처를 구성하는 포즈의 수를 변경하

표 2. 제스처를 구성하는 포즈의 개수에 따른 인식률

\begin{tabular}{|c|c|c|c|c|}
\hline $\begin{array}{c}\text { 포즈의 } \\
\text { 개수(\%) }\end{array}$ & 3 조합 & 4 조합 & 5 조합 & 6 조합 \\
\hline \hline 제스처 1 & - & - & 92 & 83 \\
\hline 제스처 2 & - & 86 & 87 & 52 \\
\hline 제스처 3 & - & 84 & 79 & 46 \\
\hline 제스처 4 & 92 & 85 & 64 & 27 \\
\hline 제스처 5 & 74 & 53 & 38 & 14 \\
\hline 제스처 6 & 92 & 95 & 85 & 52 \\
\hline 제스처 7 & 94 & 96 & 79 & 61 \\
\hline 제스처 8 & 92 & 80 & 71 & 32 \\
\hline 제스처 9 & 93 & 83 & 69 & 30 \\
\hline
\end{tabular}

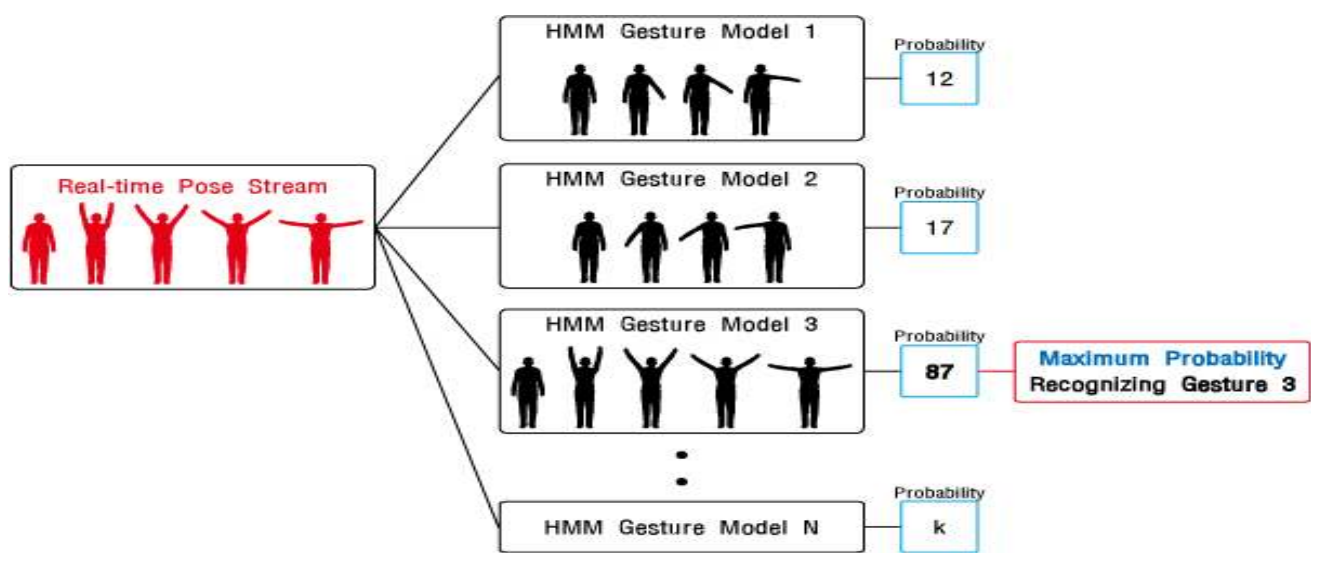

그림 6. 제스처 인식 과정(HMM모델) 


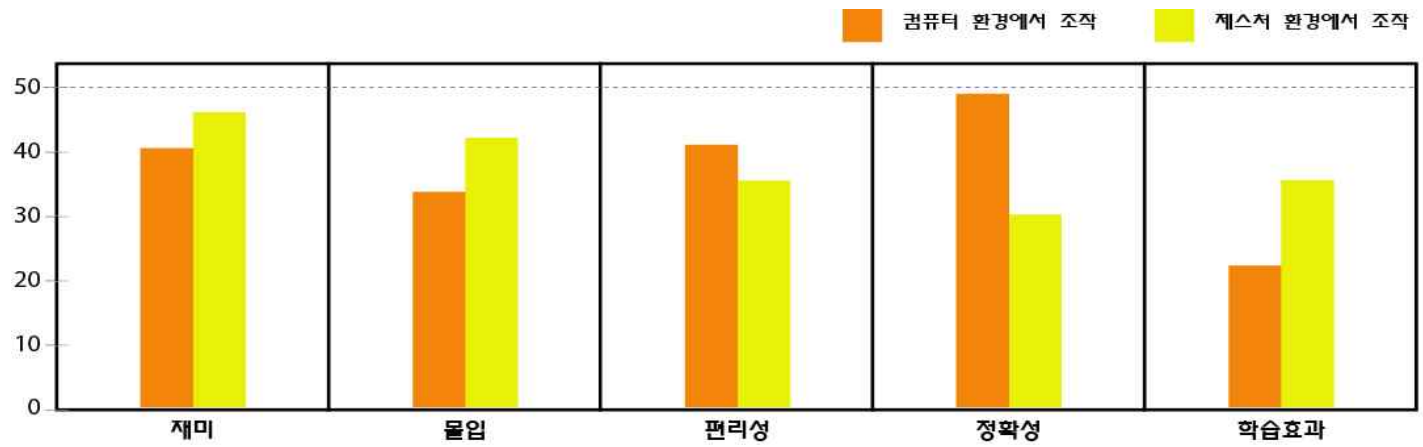

그림 7. 기존 입력장치와 제스처 기반 인터페이스 적용 결과

며 실험한 결과, 제스처를 구성하는 포즈의 수가 많 을수록 인식률이 저하되는 것을 알 수 있었다. 그 이 유는 한 개의 제스처 구성에서, 사용자 개인마다 제 스처를 실행하는 속도 및 정확한 포즈를 취하지 않는 경우가 발생한다. 이런 문제점을 해결하기 위해 제스 처를 구성하는 기본 포즈를 다양하게 정의하여 서로 다른 제스처를 구성하는 기본 포즈가 겹치는 것을 최소화해야만 한다는 것을 알 수 있었다.

\section{4 제스처 인터페이스 적용}

본 논문에서 한자 학습 콘텐츠는 시스템에서 조작 하는 버전과 일반 컴퓨터에서 조작할 수 있는 버전으 로 제작되어 실험하였다(그림 7). 실험 방법은 10 명 의 사용자가 컴퓨터 환경과 제스처 환경에서 콘텐츠 를 조작한 뒤, 5 개의 조항에 대하여 점수(1 5점)을 선택하도록 하였다.

설문 내용은 콘텐츠에 대한 오락성(재미, 몰입), 시스템 조작(편리성, 정확성)과 제스처 기반 인터페 이스와 학습 콘텐츠의 결합으로 인한 학습효과에 내 용이다. 설문 결과에 따르면 컴퓨터 환경에서 제스처 를 사용했을 때보다 기존 입력장치(키보드, 마우스) 를 이용하는 것이 편리하고 정확도가 높았다. 하지만 제스처 환경에서 조작했을 때, 책상에 앉아 일반적인 콘텐츠를 조작하여 정보전달을 얻는 것보단 직접 움 직이며 조작하는 것이 재미와 몰입감을 제공하였고, 그로 인해 학습효과가 더 뛰어난 것을 알 수 있었다.

\section{6. 결 론}

본 논문에서 제안한 콘텐츠는 기존의 단순한 입력 체계에서 벗어나 제스처 인식을 기반으로 하여 사용
자가 능동적으로 참여할 수 있도록 유도하고 사용자 의 공감각을 자극하여 사용자의 흥미를 유발시킨다. 그리고 직관적인 제스처를 사용하여 제스처 학습과 정 없이 시스템과 상호작용할 수 있다. 또한 제안된 콘텐츠를 구동하는 시스템은 다양한 상호작용 콘텐 츠와 결합하여 교육, 문화, 전시 분야 등 다양한 분야 에서 활용될 수 있다.

현재 시스템은 단일 사용자만을 인식하는 한계점 과 주변 환경의 노이즈나 포즈 오인식에 의한 제스처 인식이 잘못되는 경우가 발생한다. 향후 다수의 사용 자가 사용할 수 있는 인터페이스를 개발하고 다양한 콘텐츠 개발을 통하여 시스템의 활용 가능성을 높일 것이다. 또한 제스처 인식의 오류율을 줄이기 위해 주위 환경에 강건한 입력 인터페이스 시스템을 개발 할 것이다.

\section{참 고 문 헌}

[1] 장상수, 박혜선, 김상호, 김항준 " $\mathrm{HMM}$ 을 이용 한 제스처 기반의 게임 인터페이스," 한국정보 과학회 춘계학술발표 논문집(B), Vol. 31, No. 1, pp. 496-498, 2004.

[2] 백승국, "에듀테인먼트 콘텐츠와 미디어 문화 교육," 한국 언론학회 2006년 춘계정기학술대 회 논문집, pp.393-400, 2006.

[3] 여선민, 증강현실 기반 콘텐츠 활용 수업의 효 과성 분석, 원광대학교 교육대학원 석사학위 논 문, 2008.

[4] 김동민, 박재완, 이칠우 “제스처 인식을 이용한 실시간 상호작용 게임 시스템 구현,” 제24회 신 호처리합동 학술대회 논문집, $\mathrm{Vol} .24, \mathrm{No} .1, \mathrm{pp}$. 
74-77, 2011.

[5] Lawrence R. Rabiner, "A Tutorial on Hidden Markov Models and Selected Applications in Speech Recognition," IEEE Signal Processing Letters, Vol.10, No.1, pp. 257-286, 2003.

[6] W.T. Freeman and M. Roth, "Orientation Histograms for Hand Gesture Recognition," Intl. Workshop on Automatic Face-and GestureRecognition, IEEE Computer Society, pp 296-301, 1995.

[7] 정창욱, 강동중, "지능형 영상 감시 시스템에서 의 은닉 마르코프 모델을 이용한 특이 행동 인 식 알고리즘," 멀티미디어학회논문지, 제 11 권, 제11호, pp. 1491-1500, 2008.

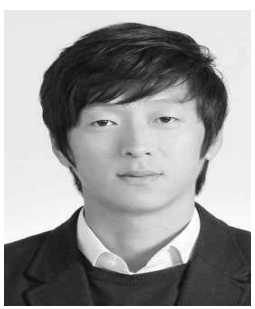

\section{송 대 현}

2007년 전주대학교 멀티미디어 공학과 학사 졸업

2009년 전남대학교 전자컴퓨터 강학과 석사 졸업

2009년 현재 전남대학교 전자컴 퓨터강학과 박사과정

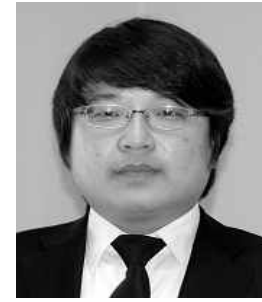

김 동 민

2010년 전남대학교 전기공학과 학 사 졸업

2010년 현재 전남대학교 전자컴 퓨터공학부 석사과정

관심분야 : 컴퓨터 비전, 임베디드 시스템

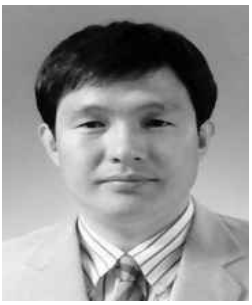

\section{이 칠 우}

1986년 중앙대학교 전자공학과 학사 졸업

1988년 중앙대학교 전자공학과 석사 졸업

1992년 동경대학교 전자공학과 박사 졸업

1992년 1995년 이미지 정보과학 연구소 수석 연구원 겸 오사카 대학 기초공학부 협력연구원

1995년 리츠메이칸 대학 정보 공학부 특별초빙강사 1992년 현재 전남대학교 전자컴퓨터공학부 교수 관심분야: 컴퓨터 비전, 지능형 휴먼 인터페이스, 디지털 콘텐츠, 컴퓨터그래픽스

관심분야 : 전통문화 콘텐츠, 전자책, 증강현실 